\title{
PERTINENCE CURVES IN FUZZY MODELING OF THE PRODUCTIVE RESPONSES OF BROILERS
}

\author{
Dian Lourençoni ${ }^{1 *}$, Paulo G. de Abreu ${ }^{2}$, Tadayuki Yanagi Junior ${ }^{3}$, Alessandro T. Campos ${ }^{3}$, \\ Silvia de N. M. Yanagi ${ }^{3}$
}

${ }^{1 *}$ Corresponding author. Universidade Federal do Vale do São Francisco/ Juazeiro - BA, Brasil.

E-mail: dian.lourenconi@univasf.edu.br | ORCID: https://orcid.org/0000-0003-1173-2381

\section{KEYWORDS}

poultry farming, production performance, artificial intelligence, fuzzy logic.

\begin{abstract}
The selection of the type of fuzzy systems pertinence curve allows a better representation of the mathematical model and a smaller simulation error. We aimed to study the effect of pertinence curves in fuzzy modeling of broiler performance, created in different production systems. For the development and testing of fuzzy models, three commercial aviaries (conventional, tunnel with negative pressure, and dark house) were evaluated over one year, totaling six lots per system. For the development of the model, the input variables were enthalpy in each rearing phase (initial: phases 1,2, and 3; growth: phase 4; and final: phase 5) and the output variables were feed intake (FE), weight gain (GP), feed conversion (FE), and the productive efficiency index (PEI). Triangular, trapezoidal, and Gaussian pertinence curves were combined and applied to represent the input and output fuzzy sets, totaling nine fuzzy models for each output variable. The combinations of pertinence curves provided adequate responses for the prediction of AL, GP, RC, and PEI. However, the selection of the types of curves should be studied on a case-by-case basis, so that the smallest possible simulation errors are obtained.
\end{abstract}

\section{INTRODUCTION}

In cutting poultry, the production environment is one of the most studied subjects to obtain increased production efficiency. For animals to express their full genetic potential, they should receive, among other requirements, adequate feeding and an aseptic environment that is thermally adjusted to the needs of chickens (Yanagi Junior et al., 2011; Abreu et al., 2012).

Broilers are capable of maintaining body temperature within relatively narrow limits through behavioral and physiological mechanisms. However, when the thermal environment goes beyond these limits, the energy used for meat production is spent in thermoregulatory processes, causing production losses (Baracho et al., 2013; Boiago et al., 2013; Santos et al., 2014).

Therefore, it is essential to develop algorithms for the control of the environment inside the aviaries. Among them, models based on artificial intelligence are gaining research interest because the fuzzy methodology has proved to be effective in research with animal comfort (Castro et al., 2012; Ponciano et al., 2012; Campos et al., 2013; Aborisade \& Stephen, 2014; Ferraz et al., 2014; Xiang-Jie, 2014; Julio et al., 2015; Mirzaee-Ghaleh et al., 2015; Schiassi et al., 2015).

However, so far fuzzy systems in the area of animal ambience have been developed only with the use of one or two types of pertinence curves, the commonly used being triangular or trapezoidal. In other areas, studies have evaluated the use of different pertinence curves, such as the work performed by Yilmaz \& Arslan (2008).

Therefore, the objective of this research was to study the effect of pertinence curves on fuzzy modeling of broiler performance, created in different commercial production systems.

\section{MATERIAL AND METHODS}

Lighting, heating, ventilation, and cooling installations and systems

For the development and testing of fuzzy systems, with different curves of pertinence, three commercial aviaries were evaluated (conventional, tunnel with negative pressure, and dark house) for the breeding of broilers, over 1 year. The aviaries are located in the municipality of

${ }^{2}$ EMBRAPA Suínos e Aves/ Concórdia - SC, Brasil.

${ }^{3}$ Universidade Federal de Lavras/ Lavras - MG, Brasil.

Received in: 11-12-2018

Accepted in: 2-6-2019 
Concórdia, Santa Catarina, with a Cfa climate according to Köppen, that is, a humid temperate climate with a hot summer (Peel et al., 2007).

The aviary in the conventional system had the following characteristics: width of $12 \mathrm{~m}$, length of $100 \mathrm{~m}$, and height of $2.4 \mathrm{~m}$; coverage in two waters with tiles of asbestos cement of $6 \mathrm{~mm}$ thickness; orientation of the ridge along the East-West direction; lateral walls of $0.45 \mathrm{~m}$ height; lining and lateral curtains in yellow color; two lines of illumination with 16 tubular fluorescent lamps of $40 \mathrm{~W}$, totaling 32 lamps; heating of the chicks in the initial phases by irradiation, using a firewood drum and gas bell; ten 3 blade fans with a single-phase $0.5 \mathrm{HP}$ induction motor and a flow between 240 and $280 \mathrm{~m}^{3} \mathrm{~min}^{-1}$, arranged in a crossed ventilation system (positive pressure); four lines each with ten high-pressure nebulizers (180 $\left.\mathrm{kgf} \mathrm{cm}^{-2}\right)$, distributed longitudinally in the aviary, totaling 40 water emitters, with a flow of $6.5 \mathrm{~L} \mathrm{~h}^{-1}$; and a three-phase 7 HP motor pump system. The bed was composed of a new razor at the beginning of the first lot.

The fans were activated in three stages: In stage 1, four fans were turned on with a dry bulb temperature ( $\left.t_{b s}\right)$ of $27.0^{\circ} \mathrm{C}$; in stage 2 , eight fans were turned on at $27.2^{\circ} \mathrm{C}$ and stage 3 (10 fans) turned on from $27.5^{\circ} \mathrm{C}$. The nebulizers were activated when the relative humidity $(\mathrm{RH})$ was less than $70 \%$. The light program adopted from day 1 to day 3 was 24 hours of light (L) and 0 hours of darkness (E) (24L:0E); day 4 to day 7, 22L:2E; day 8 to day 21, 20L:4E; and day 22 to slaughter, $16 \mathrm{~L}: 8 \mathrm{E}$. Water and feed were supplied at will.

The aviary in the negative pressure system had the following characteristics: a width of $12 \mathrm{~m}$, length of $100 \mathrm{~m}$, and ceiling height of $2.4 \mathrm{~m}$; coverage in two waters with French-type ceramic tiles; orientation of the ridge along the East-West direction; side walls of $0.43 \mathrm{~m}$ in height; lining and side curtains in yellow color; two lighting lines with 16 compact fluorescent lamps of $25 \mathrm{~W}$, totaling 32 lamps; heating of the chicks in the initial stages performed with gas hoods; ventilation in the tunnel mode (negative pressure) with 8 three-blade exhaust fans, diameter of $1.80 \mathrm{~m}$, singlephase $1 \mathrm{HP}$ induction motor, and flow between 441 and 564 $\mathrm{m}^{3} \mathrm{~min}^{-1}$; and eight lines with eight high-pressure nebulizers $\left(180 \mathrm{kgf} \mathrm{cm}^{-2}\right.$ ) distributed parallel to the width of the aviary, totaling 64 water emitters, with a flow of $6.5 \mathrm{~L} \mathrm{~h}^{-1}$ and a motor pump system of two biphasic motors. The bed was composed of a new razor at the beginning of the first lot.

The hoods were operated in four stages: stage 1 (two hoods) corresponded to the minimum ventilation condition, always remaining on; stage 2 (four hoods) connected with $\mathrm{t}_{\mathrm{bs}} \geq 28{ }^{\circ} \mathrm{C}$; stage 3 ( six hoods) connected with $\mathrm{t}_{\mathrm{bs}} \geq 29^{\circ} \mathrm{C}$; and stage 4 (eight hoods) connected with $\mathrm{t}_{\mathrm{bs}} \geq 30^{\circ} \mathrm{C}$. The nebulizers were activated with $\mathrm{t}_{\mathrm{bs}} \geq 31{ }^{\circ} \mathrm{C}$. The light program adopted from day 1 to day 2 was $24 \mathrm{~L}: 0 \mathrm{E}$; day 3 to day 7, 23L:1E; day 8 to day 35, 14L:10E; and day 36 to slaughter 22L:2E. Water and feed were supplied at will.

The aviary in the dark house system had the following characteristics: $12 \mathrm{~m}$ wide, $100 \mathrm{~m}$ long, and 2.2 $\mathrm{m}$ high; two-water cover with French-style ceramic tiles; East-West ridge orientation; 0.45 m-high side walls; black side walls on the inside and silver on the outside; two lighting lines with 20 incandescent bulbs of $100 \mathrm{~W}$, totaling 40 bulbs; heating of the chicks was performed with a firewood furnace system; ventilation in the tunnel mode (negative pressure) with eight hoods of three blades, diameter of $1.80 \mathrm{~m}$, three-phase $1 \mathrm{HP}$ induction motor having flow between 441 and $564 \mathrm{~m}^{3} \mathrm{~min}^{-1}$; eight lines with eight high-pressure nebulizers $\left(180 \mathrm{kgf} \mathrm{cm}^{-2}\right)$ distributed parallel to the width of the aviary, totaling 64 water emitters, with a flow of $6.5 \mathrm{~L} \mathrm{~h}^{-1}$ and a three-phase 7 HP motor-pump system; evaporative cooling system of the type moistened brick plate, with two plates of $15 \mathrm{~m}$ long each and three lines with 18 nebulizers distributed externally in the brick plate (totaling 54 water emitters). The bed was composed of a new razor at the beginning of the first lot.

The hoods were driven in four stages: stage 1 (two hoods) corresponding to minimum ventilation $\left(\mathrm{t}_{\mathrm{bs}} \leq 22^{\circ} \mathrm{C}\right)$; stage 2 (four hoods) driven with a $\mathrm{t}_{\mathrm{bs}}$ of $23{ }^{\circ} \mathrm{C}$; stage 3 (six hoods) driven with a $\mathrm{t}_{\mathrm{bs}}$ of $24^{\circ} \mathrm{C}$; and stage 4 (eight hoods) driven with a $\mathrm{t}_{\mathrm{bs}}$ of $25^{\circ} \mathrm{C}$. The evaporative plaques and nebulizers were activated with UR less than $70 \%$ and $65 \%$, respectively. The light program adopted from day 1 to day 3 was 24L:0E; from day 4 to day 21, 10L:14E; from day 22 to day $35,8 \mathrm{~L}: 16 \mathrm{E}$; and from day 36 to slaughter, $22 \mathrm{~L}: 2 \mathrm{E}$. Water and feed were supplied at will.

\section{Animals and measurements}

For each aviary evaluated, the thermal environment was monitored every 2 hours, during the entire life cycle of the birds, in six flocks of Cobb broilers. The variables evaluated were the thermal and productive responses of the birds.

The thermal variables ( $\mathrm{t}_{\mathrm{bs}}$ and UR) were collected at 12 points evenly distributed inside the aviary and one external point (Figure 1), at a height of $30 \mathrm{~cm}$ from the bed, recorded every 2 hours by six consecutive lots, using sensors coupled to a data logger, for the recording of $t_{b s}$ and UR (Homis 404A, accuracy of $\pm 0.5^{\circ} \mathrm{C}$ and resolution of $0.1{ }^{\circ} \mathrm{C} 107$ for $t_{b s}$ and accuracy of $\pm 2.5 \%$ and resolution of $0.1 \%$ for UR). 


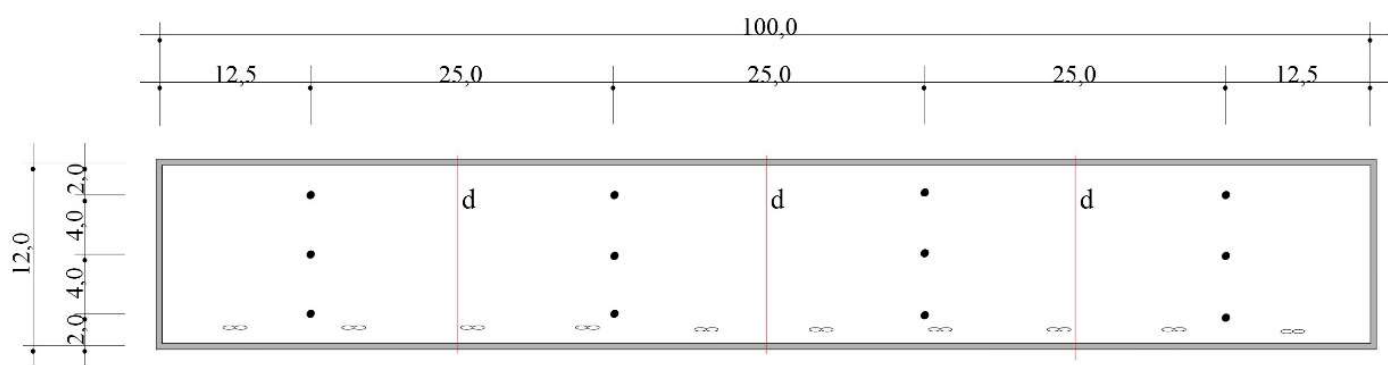

A

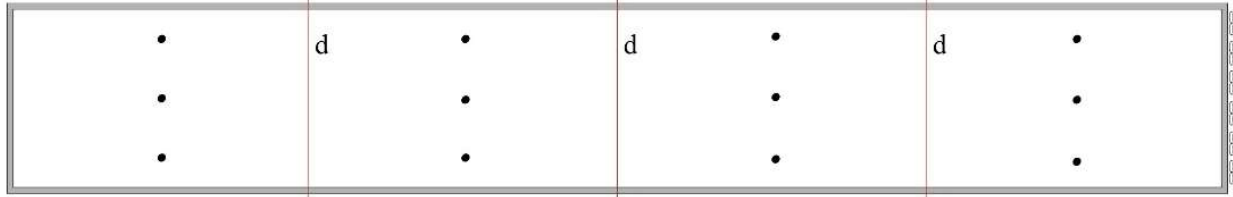

B

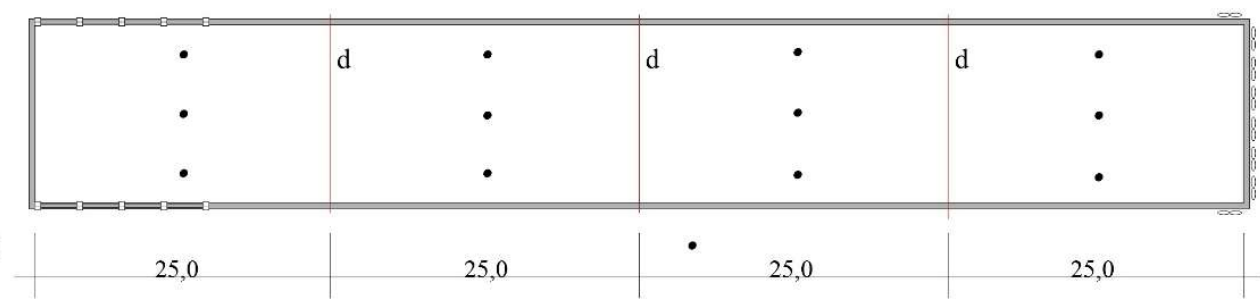

\begin{tabular}{|l|c|cl|}
\hline & Collection points & $=$ & Evaporative plates \\
\hline$\infty$ & Fans/Exhausters & $\mathrm{d}$ & Internal divisions \\
\hline
\end{tabular}

FIGURE 1. Sketch of the aviaries: (A) conventional system, (B) negative pressure system, and (C) dark house system with distribution scheme of the sensors.

In addition to $\mathrm{t}_{\mathrm{bs}}$ and $\mathrm{UR}$, the indoor environment was characterized by enthalpy, calculated by [eq. (1)] (Albright, 1990).

$$
\mathrm{H}=1.006 \mathrm{t}_{\mathrm{bs}}+\mathrm{W}\left(2501+1.805 \mathrm{t}_{\mathrm{bs}}\right)
$$

Where,

$\mathrm{H}$ is the enthalpy $\left(\mathrm{kJ} \mathrm{kg}_{\text {dry air }}{ }^{-1}\right)$;

$\mathrm{t}_{\mathrm{bs}}$ is dry air bulb temperature $\left({ }^{\circ} \mathrm{C}\right)$,

$\mathrm{W}$ is the mixing ratio $\left(\mathrm{kg}_{\mathrm{w} \text { atervapor }} \mathrm{kg}_{\mathrm{dry}} \mathrm{air}^{-1}\right)$.

W was calculated by [eq. (2)] as a function of the current vapor pressure whater (ea, $\mathrm{kPa}$ ) and the local atmospheric pressure $\left(\mathrm{P}_{\mathrm{atm}}, \mathrm{kPa}\right)$.

$$
\mathrm{W}=0,622\left(\mathrm{ea} / \mathrm{P}_{\mathrm{atm}}\right)
$$

The productive responses evaluated were feed intake (FI), weight gain (WG), feed conversion (FC), and productive efficiency index (PEI). The $\mathrm{CR}$ was calculated by dividing the amount of feed consumed during the production cycle considered by the period in days. The GP was obtained by the difference between the live weight of the birds at the end and beginning of the production cycle considered. The AC was obtained by the relationship between the amount of feed consumed and the weight gain corresponding to the production cycle considered. The PEI (dimensionless), which is an index that takes into account live weight $(\mathrm{P}, \mathrm{kg})$, viability $(\mathrm{V}, \%)$, age (I, days), and feed conversion $\left(\mathrm{AC}, \mathrm{g}^{-1}\right)$, was calculated by [eq. (3)]. Viability is the difference between birds housed and those removed for slaughter, in percentage.

$$
\mathrm{IEP}=((\mathrm{P} \times \mathrm{V}) /(\mathrm{I} \times \mathrm{CA})) \times 100
$$

\section{Development and validation of fuzzy systems with different curves}

As used by several authors, the Mandani inference method (Mandani, 1976) was used to develop the different fuzzy models (Ponciano et al., 2012; Schiassi et al., 2015). This method brings as an answer a fuzzy set originated from the combination of input values with their respective degrees of pertinence, through the minimum operator and then by the superposition of rules, through the maximum operator (Leite et al., 2010). The input variables were defined as enthalpies $(\mathrm{H})$ in the different phases of the chicken life (Table 1). 
TABLE 1. Lower and upper temperature limits and ideal enthalpies for broilers at each stage of life.

\begin{tabular}{|c|c|c|c|}
\hline \multirow[b]{2}{*}{ Life phase (description) } & \multicolumn{3}{|c|}{ Ideal lower and upper limits } \\
\hline & $\begin{array}{c}\text { Air } \\
\text { temperature } \\
\left({ }^{\circ} \mathrm{C}\right)\end{array}$ & $\begin{array}{c}\text { Relative } \\
\text { humidity (\%) }\end{array}$ & $\begin{array}{l}\text { Enthalpy } \\
\text { limits }(\mathbf{H}) \\
\left(\mathrm{kJ} \mathrm{kg}_{\text {dry }}{ }^{-1}\right)\end{array}$ \\
\hline 1 (1st week of life - initial phase) & $32-34$ & $60-80$ & $80.0-91.7$ \\
\hline 2 (2nd week of life - initial phase) & $28-32$ & $60-80$ & $72.0-86.5$ \\
\hline 3 (3rd week of life - initial phase) & $26-28$ & $60-80$ & $68.2-77.1$ \\
\hline 4 (4th and 5th weeks of life - growth phase) & $18-26$ & $60-80$ & $54.8-72.8$ \\
\hline 5 (6th week of life - final phase) & $18-24$ & $60-80$ & $54.8-68.7$ \\
\hline
\end{tabular}

Source: Adapted from Cândido et al. (2016), Cassuce et al. (2013), and Medeiros et al. (2005).

The limits of comfort and thermal discomfort, based on enthalpy, for each phase of life of broilers were calculated through the limits of temperature and relative humidity indicated by several authors for each phase of the life of birds (Table 1).

Through the combinations of the life phases of chickens and enthalpy $(\mathrm{H}), 243$ rules were defined, and for each rule, a weighting factor equal to 1 was assigned, because all rules have the same importance in determining the system responses (Ponciano et al., 2012; Yanagi Junior et al., 2012; Schiassi et al., 2013; Schiassi et al., 2014).

The rules were defined in the form of language sentences based on data collected experimentally and with the help of four specialists, chosen according to the methodology proposed by Cornelissen et al. (2002), employed by Yanagi Junior et al. (2012) and Schiassi et al. (2015).

Based on the input variables, the different fuzzy systems predict the output variables FI, WG, FC, and PEI. Defuzzification was performed using the center of gravity method (Centroide or Area Center), which considers all the output alternatives, converting the fuzzy set originated by the inference into a numerical value (Leite et al., 2010). For each of these output variables, the pertinence curves of the input and output variables were defined by combining three distinct curves - triangular, trapezoidal, and Gaussian - totaling nine models for each variable, as listed in Table 2.

TABLE 2. Combinations of the pertinence curves in the input and output variables of fuzzy systems.

\begin{tabular}{ccc}
\hline Fuzzy system & Input variable & Output variable \\
\hline 1 & Triangular & Triangular \\
2 & Triangular & Trapezoidal \\
3 & Triangular & Gaussian \\
4 & Trapezoidal & Triangular \\
5 & Trapezoidal & Trapezoidal \\
6 & Trapezoidal & Gaussian \\
7 & Gaussian & Triangular \\
8 & Gaussian & Trapezoidal \\
9 & Gaussian & Gaussian \\
\hline
\end{tabular}

To validate the fuzzy systems, the data measured in the aviaries were used. The simulations were carried out with the help of Matlab ${ }^{\circledR}$ Fuzzy Toolbox ${ }^{\circledR}$, software version 7.13.0.564 (R2011b). In the evaluation of the proposed models, the simulated and observed productive responses were compared using standard deviation and percentage error.

\section{RESULTS AND DISCUSSION}

The adjustments of the fuzzy models were made based on the interval of data collected experimentally (Table 3), and the intervals for each function of pertinence of the output variables were adopted to result in the smallest possible errors, when compared with the data obtained experimentally. 
TABLE 3. Mean input and output values collected in experiments and used in fuzzy systems.

\begin{tabular}{|c|c|c|c|c|c|c|c|c|c|c|}
\hline \multirow{3}{*}{$\begin{array}{c}\text { Commercial } \\
\text { production } \\
\text { systems }\end{array}$} & \multirow{3}{*}{ Lot } & \multirow{2}{*}{\multicolumn{5}{|c|}{$\begin{array}{c}\text { Input variables } \\
\text { Enthalpy in life stages } \\
\left(\mathrm{kJ} \mathrm{kg} \mathrm{dry} \mathrm{ar}^{-1}\right)\end{array}$}} & \multicolumn{4}{|c|}{ Output variables } \\
\hline & & & & & & & \multirow[t]{2}{*}{ FI (g) } & \multirow[t]{2}{*}{ WG (g) } & \multirow{2}{*}{$\begin{array}{c}\mathrm{FC} \\
\left(\mathrm{g} \mathrm{g}^{-1}\right)\end{array}$} & \multirow[t]{2}{*}{$\mathbf{P E}$} \\
\hline & & 1 & 2 & 3 & 4 & 5 & & & & \\
\hline \multirow{6}{*}{ Dark house } & 1 & 74.9 & 66.5 & 67.9 & 66.7 & 65.1 & 132.0 & 3137 & 1.61 & 333 \\
\hline & 2 & 73.0 & 70.6 & 69.4 & 70.6 & 70.2 & 116.9 & 2807 & 1.47 & 387 \\
\hline & 3 & 74.8 & 72.5 & 70.3 & 68.9 & 65.0 & 108.7 & 2528 & 1.51 & 383 \\
\hline & 4 & 73.5 & 73.6 & 70.7 & 68.9 & 68.1 & 111.5 & 2546 & 1.49 & 392 \\
\hline & 5 & 73.2 & 73.6 & 70.8 & 68.9 & 67.0 & 124.5 & 3018 & 1.44 & 400 \\
\hline & 6 & 70.5 & 67.9 & 67.7 & 65.2 & 60.6 & 116.1 & 2820 & 1.45 & 406 \\
\hline \multirow{6}{*}{ Conventional } & 1 & 72.7 & 64.2 & 72.6 & 66.7 & 67.1 & 112.9 & 2422 & 1.90 & 268 \\
\hline & 2 & 74.2 & 70.6 & 70.2 & 72.2 & 72.5 & 109.1 & 2417 & 1.75 & 300 \\
\hline & 3 & 80.4 & 70.7 & 71.9 & 70.0 & 69.3 & 109.4 & 2469 & 1.70 & 214 \\
\hline & 4 & 69.6 & 73.5 & 71.2 & 70.9 & 68.9 & 119.2 & 2985 & 1.55 & 347 \\
\hline & 5 & 73.8 & 70.4 & 68.0 & 69.3 & 65.0 & 118.8 & 2818 & 1.70 & 314 \\
\hline & 6 & 77.9 & 73.2 & 74.6 & 70.3 & 63.8 & 116.4 & 2815 & 1.58 & 352 \\
\hline \multirow{6}{*}{$\begin{array}{l}\text { Negative } \\
\text { pressure }\end{array}$} & 1 & 73.1 & 66.4 & 73.9 & 68.2 & 67.7 & 119.3 & 2730 & 1.65 & 328 \\
\hline & 2 & 73.2 & 74.0 & 72.1 & 73.3 & 71.8 & 100.5 & 2113 & 1.68 & 325 \\
\hline & 3 & 77.8 & 75.7 & 71.2 & 70.0 & 68.8 & 121.4 & 3081 & 1.46 & 370 \\
\hline & 4 & 78.0 & 75.8 & 71.7 & 70.2 & 69.1 & 114.7 & 2829 & 1.46 & 393 \\
\hline & 5 & 77.1 & 73.2 & 70.7 & 69.3 & 67.4 & 114.2 & 2888 & 1.45 & 383 \\
\hline & 6 & 73.2 & 71.8 & 73.0 & 68.4 & 65.3 & 112.8 & 2827 & 1.44 & 404 \\
\hline
\end{tabular}

The types of pertinence curves that best represented the data set of the input and output variables for the wheelchair and WG were Gaussian and triangular, respectively (Table 4). The standard deviations and mean percentage errors observed were 3.99 and $4.86 \%$ and 141.42 and $7.75 \%$ for the wheelchair and $\mathrm{WG}$, respectively. Whereas the use of the Gaussian pertinence curve for the input variables is not found in the literature, several authors proposed the use of the triangular pertinence curve for the output variables (Ponciano et al., 2012; Abreu et al., 2015; SCHIASSI et al., 2015). The mean standard deviations and percentage errors related to the systems adjusted by these authors for the variable FI were $1.19 \mathrm{~g}$ and $0.20 \%$, $4.31 \mathrm{~g}$ and $2.38 \%$ and $4.15 \mathrm{~g}$ and $2.12 \%$, and for WG were $2.09 \mathrm{~g}$ and $0.49 \%, 4.76 \mathrm{~g}$ and $2.94 \%$ and $3.10 \mathrm{~g}$ and $2.74 \%$, respectively.

TABLE 4. Mean standard deviations and mean percentage errors (in parentheses) between measured and simulated feed consumption values (FI, g), mean weight gain (WG, g), feed conversion (FC, $\mathrm{g}^{-1}$ ) and production efficiency index (PEI, dimensionless) for the different pertinence curves used in the development of fuzzy systems.

\begin{tabular}{|c|c|c|c|}
\hline Exit & & FI & \\
\hline Entry & Triangular & Trapezoidal & Gaussian \\
\hline Triangular & $4.70(5.58 \%)$ & $4.58(5.45 \%)$ & $4.58(5.45 \%)$ \\
\hline Trapezoidal & $4.05(4.92 \%)$ & $4.16(5.05 \%)$ & $4.16(5.06 \%)$ \\
\hline Gaussian & $3.99(4.86 \%)$ & $4.03(4.90 \%)$ & $4.08(4.96 \%)$ \\
\hline
\end{tabular}

\begin{tabular}{lccc}
\hline Entry & Exit & $\begin{array}{c}\text { WG } \\
\text { Trapezoidal }\end{array}$ & Gaussian \\
\hline Triangular & Triangular & $161.85(8.52 \%)$ & $161.85(8.52 \%)$ \\
Trapezoidal & $161.85(8.52 \%)$ & $143.78(7.89 \%)$ & $143.78(7.89 \%)$ \\
Gaussian & $143.78(7.89 \%)$ & $141.42(7.75 \%)$ & $141.42(7.75 \%)$ \\
\hline
\end{tabular}

\begin{tabular}{lccc}
\hline & Exit & FC & Gaussian \\
Entry & Triangular & Trapezoidal & $0.09(8.51 \%)$ \\
Triangular & $0.09(8.51 \%)$ & $0.09(8.51 \%)$ & $0.06(5.03 \%)$ \\
Trapezoidal & $0.06(5.03 \%)$ & $0.06(5.03 \%)$ & $0.06(5.19 \%)$ \\
Gaussian & $0.06(5.19 \%)$ & $0.06(5.19 \%)$ & \\
\hline
\end{tabular}

\begin{tabular}{lccc}
\hline & Exit & PEI & Gaussian \\
Entry & Triangular & $34.06(14.16 \%)$ & $34.06(14.16 \%)$ \\
Triangular & $34.06(14.16 \%)$ & $24.24(12.13 \%)$ & $24.24(12.13 \%)$ \\
Trapezoidal & $24.24(12.13 \%)$ & $22.90(11.58 \%)$ & $22.90(11.58 \%)$ \\
Gaussian & $22.90(11.58 \%)$ & & \\
\hline
\end{tabular}


The trapezoidal pertinence curve resulted in lower mean values of standard deviation and percentage error for $\operatorname{AL}$ (0.06 and 4.69\%, respectively) when used in input and output variables. This behavior corroborates the results of fuzzy systems developed by several authors (Oliveira et al., 2005; Pandorfi et al., 2007; Santos et al., 2009).

Regarding the PEI, the type of pertinence curve that best represented the set of input and output data was the Gaussian curve, with a mean standard deviation of 22.20 and mean percentage error of $11.35 \%$. Yilmaz and Arslan (2008), while evaluating models with different pertinence curves in the input variables for the calculation of geographical heights, in Istanbul (Turkey), emphasize that the model using the Gaussian pertinence curve provided the best results.

The fuzzy systems composed of triangular pertinence curves in the input variables resulted in higher mean values of standard deviation and percentage error. This behavior, in general, is owing to the existence of welldefined bands for the input fuzzy sets with a gradual change between these sets. For these variables, the existence of a point with a degree of pertinence 1 and linear variation from this point was not adequate. Moreover, the behavior of the Gaussian curve is also more similar to the variations observed in living beings that do not always exhibit behaviors described by triangular or rectangular curves.

It can be observed that the mean standard deviations and average percentage errors (in brackets) for the different fuzzy systems varied between $3.99 \mathrm{~g}(4.86 \%)$ and $4.70 \mathrm{~g}$ $(5.58 \%)$ for RC, $141.42 \mathrm{~g}(7.75 \%)$ and $163.42 \mathrm{~g}(8.59 \%)$ for GP, $0.06 \mathrm{~g}^{-1}(4.96 \%)$ and $0.09 \mathrm{~g}^{-1}(8.51 \%)$ for AC, and 22.20 $(11.35 \%)$ and $34.41(14.26 \%)$ for PEI. Therefore, all the proposed models considering the combination of the different pertinence curves are able to estimate with some efficiency the productive performance of broilers.

However, the selection of the type of pertinence curve or a combination of several types depends on the behavior of the variable to be studied, and descriptive statistics can be used to select the best configuration for the development of the fuzzy system, allowing reduction of errors. For the variables studied, the observed reductions in mean values of standard deviation and mean percentage error were $0.71 \mathrm{~g}$ and $0.72 \%$ for RC, $22.00 \mathrm{~g}$ and $0.84 \%$ for GP, $0.03 \mathrm{~g} \mathrm{~g}^{-1}$ and $3.55 \%$ for $\mathrm{AL}$, and 12.21 and $2.91 \%$ for PEI.

\section{CONCLUSIONS}

The triangular, trapezoidal, and Gaussian pertinence curves used in the development of fuzzy systems provide adequate responses to predict average daily feed intake, weight gain, feed conversion, and broiler production efficiency index.

\section{ACKNOWLEDGMENTS}

The authors express their thanks to FAPEMIG, CAPES, CNPq, and EMBRAPA Swine and Poultry for supporting this research.

\section{REFERENCES}

Aborisade DO, Stephen O (2014) Poultry house temperature control using Fuzzy-PID controller. International Journal of Engineering Trends and Technology 11(6):310-314.
Abreu LHP, Yanagi Junior T, Fassani EJ, Campos AT, Lourençoni D (2015) Fuzzy modeling of broiler performance, raised from 1 to 21 days, subject to heat stress. Engenharia Agrícola 35(6):967-978.

Abreu PG de, Abreu VMN, Coldebella A, Hassemer MJ, Tomazelli IL (2012) Medidas morfológicas em função do peso e da idade da ave, por meio de imagens. Revista Brasileira de Engenharia Agrícola e Ambiental 16(7):795-801.

Albright LD (1990) Environment control for animals and plants. St. Joseph, American Society of Agricultural Engineers Michigan, 453p. (ASAE Textbook, 4).

Baracho MS, Cassiano JÁ, Nääs IA, Tonon GS, Garcia RG, Royer AFB, Santana MR (2013) Ambiente interno em galpões de frango de corte com cama nova e reutilizada. Agrarian 6(22):473-478.

Boiago MM, Barba H, Souza PA, Scatolini AM, Ferrari FB, Giampietro-Ganeco A (2013) Desempenho de frangos de corte, alimentados com dietas contendo diferentes fontes de selênio, zinco e manganês, criados sob condições de estresse térmico. Arquivo Brasileiro de Medicina Veterinária e Zootecnia 65(1):241-247.

Campos AT, Castro JO, Schiassi L, Yanagi Junior T, Pires MFÁ, Mattioli CC (2013) Prediction of free-stall occupancy rate in dairycattle barns through fuzzy sets. Engenharia Agrícola 33(1):1079-1089.

Cândido MG, Tinôco IDF, Pinto FDADC, Santos NT, Roberti RP (2016) Determination of thermal comfort zone for early-stage broilers. Engenharia Agrícola 36(5):760-767.

Cassuce DC, Tinoco IDF, Baeta FC, Zolnier S, Cecon PR, Vieira MDA (2013) Atualização da temperatura de conforto térmico para frangos de corte de até 21 dias de idade. Engenharia Agrícola 33(1):28-36.

Castro JO, Veloso AV, Yanagi Junior T, Fassani EJ, Schiassi L, Campos AT (2012) Estimate of the weight of Japanese quail eggs through fuzzy sets theory. Ciência e Agrotecnologia 36(1):108-116.

Cornelissen AMG, Van Den Berg J, Koops WJ, Kaymak U (2002) Elicitation of expert knowledge for fuzzy evaluation of agricultural production systems. Agriculture, ecosystems e environment, 95(1):1-18.

Ferraz PFP, Yanagi Junior T, Julio YFH, Castro JO, Gates RS, Reis GM, Campos AT (2014) Predicting chick body mass with artificial intelligence-based models. Pesquisa Agropecuária Brasileira 49(7):559-568.

Julio YFH, Yanagi Junior T, Pires MFA, Lopes MA, Lima RR (2015) Fuzzy system to predict physiological responses of Holstein cows in southeastern Brazil. Revista Colombiana de Ciências Pecuárias 28(1):42-53.

Leite MS, Fileti AMF, Silva FV (2010) Desenvolvimento e aplicação experimental de controladores fuzzy e convencional em um bioprocesso. Revista Controle \& Automação 21(2):147-158.

Mandani EH (1976) Advances in the linguistic syntesis of fuzzy controllers. International Journal of Man-Machine Studies 8(6):669-678. 
Medeiros CM, Baêta FC, Oliveira RFM (2005) Efeitos da temperatura, umidade relativa e velocidade do ar em frangos de corte. Engenharia na Agricultura 13(4):277-286.

Mirzaee-Ghalehv E, Omid M, Keyhani A, Dalvand MJ (2015) Comparison of fuzzy and on/off controllers for winter season indoor climate management in a model poultry house. Computers and Electronics in Agriculture 110:187-195.

Oliveira HL, Amendola M, Nääs IA (2005) Estimativa das condições de conforto térmico para avicultura de postura usando a teoria dos conjuntos fuzzy. Engenharia Agrícola 25(2):300-307.

Pandorfi H, Silva IJO, Guiselini C, Piedade SMS (2007) Uso da lógica fuzzy na caracterização do ambiente produtivo para matrizes gestantes. Engenharia Agrícola 27(1):83-92.

Peel MC, Finlayson BL, Mcmahon TA (2007) Updated world map of the Köppen-Geiger climate classification. Hydrology Earth System Sciences 11:1633-1644.

Ponciano PF, Yanagi Junior T, Schiassi L, Campos AT, Nascimento JWB (2012) Sistema fuzzy para predição do desempenho produtivo de frangos de corte de 1 a 21 dias de idade. Engenharia Agrícola 32(3):446-458.

Santos GB, Sousa IF, Brito CO, Santos VS, Barbosa RJ, Soares C (2014) Estudo biológico das regiões litorâneas, agreste e semiárida do estado de Sergipe para a avicultura de corte e postura. Ciência Rural 44(1):123-128.
Santos RC, Nääs IA, Moreira FR, Gomes Filho R (2009) Aplicação da lógica nebulosa na simulação de estro de vacas leiteiras. Enciclopédia Biosfera 5(8):1-6.

Schiassi L, Melo NSM, Tavares GF, Souza ÍP, Araújo HB, Della Giustina C (2013) Modelagem fuzzy em parâmetros de bem-estar humano. Nativa 1(1):8-12.

Schiassi L, Yanagi Junior T, Damasceno FA, Saraz JAO, Amaral AG (2014) Thermal-Acoustic Comfort Index for Workers of Poultry Houses Using Fuzzy Modeling. International Journal of Engineering Research and Applications 4(9):60-64.

Schiassi L, Yanagi Junior T, Reis GM, Abreu LHP, Campos AT, Castro JO (2015) Modelagem fuzzy aplicada na avaliação do desempenho de frangos de corte. Revista Brasileira de Engenharia Agrícola e Ambiental 19(2):140-146.

Xiang-Jie N (2014) Research on the temperature control algorithm of the poultry farm. Applied Mechanics and Materials 602:1206-1209.

Yanagi Junior T, Amaral AG, Teixeira VH, Lima RR (2011) Caracterização espacial do ambiente termoacústico e de iluminância em galpão comercial para criação de frangos de corte. Engenharia Agrícola 31(1):1-12.

Yanagi Junior T, Schiassi L, Abreu LHP, Barbosa JA, Campos AT (2012) Procedimento fuzzy aplicado à avaliação da insalubridade em atividades agrícolas. Engenharia Agrícola 32(3):423-434.

Yulmaz M, Arslan E (2008) Effect of the Type of Membership Function on Geoid Height Modelling with Fuzzy Logic. Survey Review 40(310):379-391. 